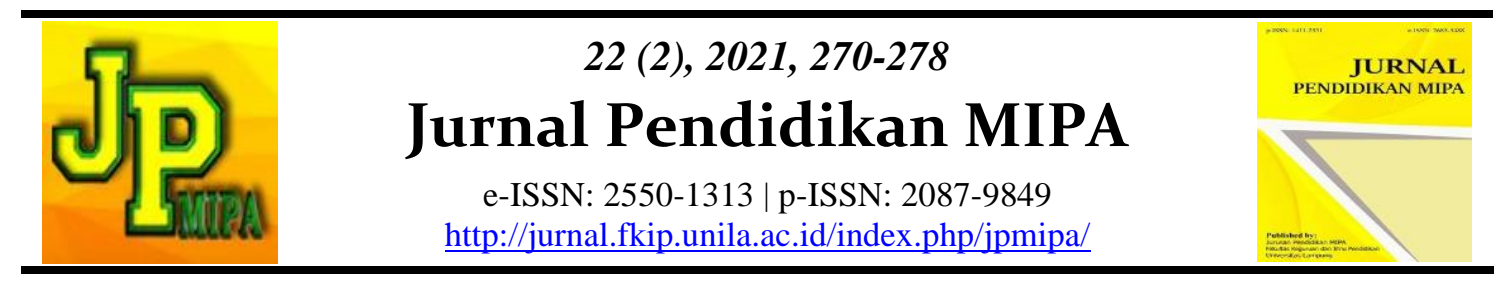

\title{
Effectiveness Blended Learning During Pandemic in Indonesia: A Meta-Analysis
}

\author{
Ronal Watrianthos ${ }^{1, *}$, Rosmidah Hasibuan ${ }^{2}$, Dheo Rimbano ${ }^{3}$, Nizwardi Jalinus ${ }^{4}$, Rijal Abdullah ${ }^{4}$ \\ ${ }^{1}$ Department of Computer Engineering, Universitas Al Washliyah, Indonesia \\ ${ }^{2}$ Department of Biology Education, Universitas Labuhanbatu, Indonesia \\ ${ }^{3}$ Department of Management, Universitas Bina Insan, Indonesia \\ ${ }^{4}$ Department of Technology and Vocational Education, Universitas Negeri Padang, Indonesia
}

\begin{abstract}
The current blended learning method, which mixes online and traditional classroom instruction, is appropriate for the epidemic. According to various research studies, blended learning benefits students by allowing them to study independently without regard for location or time constraints. This article explores and describes the use of the blended learning paradigm during a pandemic using a meta-analysis technique. The objective is to determine the effect of blended learning on learning outcomes; according to the conclusions of a research released in 2021 based on ten published articles, employing the blended learning approach greatly improved learning outcomes during the pandemic, with an effect size value of 1.21. However, the outcomes of this study suggest that publication bias exists as a result of an unbalanced distribution of effect sizes.
\end{abstract}

Keywords: blended learning, pandemic, meta-analysis

Abstrak: Metode blended learning saat ini menjadi metode yang paling sesuai dimasa pandemic dengan menggabungkan pembelajaran online dengan metode kelas berbasis tradisional. Beberapa studi literatur menyatakan blended learning memberikan keuntungan bagi siswa untuk dapat belajar secara fleksibel, bebas, tanpa terhalang ruang dan waktu. Penelitian ini mengkaji dan memberikan penjelasan mengenai penerapan model blended learning di masa pandemic dengan metode meta-analisis. Tujuannya adalah mengetahui pengaruh Blended Learning terhadap hasil belajar. Hasil study pada sepuluh artikel yang diteliti yang terbit pada 2021 menyatakan penerapan model blended learning di masa pandemic memberi pengaruh yang tinggi terhadap hasil belajar dengan nilai efek size sebesar 1.21. Namun hasil penelitian ini memperlihatkan indikasi terjadinya publikasi bias karena distribusi efek size yang tidak simetris.

Kata kunci: blended learning, pandemic, meta analisis.

\section{- INTRODUCTION}

The epidemic has prompted Indonesia's educational system to speed its transformation to meet the demands of the digital era. The Internet has developed into a great source of knowledge and a viable alternative method of education. In times of pandemics, the Internet motivates students, makes teaching more interesting, and promotes critical lessons to be distinctive (Firman Edi et al., 2021). Throughout the epidemic, educators worked diligently to adapt to new teaching techniques to reduce the losses. During the Covid-19 epidemic, educators also become learners and jointly adjust to online teaching and learning (Samsir et al., 2021).

By integrating online and conventional classroom-based instruction, blended learning is the proper way during pandemic times (face-to-face learning). It necessitates the actual presence of teachers and students and some student control over time, location,

Ronal Watrianthos et al.

Email: ronal.watrianthos@gmail.com
DOI: http://dx.doi.org/10.23960/jpmipa/v22i2.pp270-278

Received: 19 November 2021

Accepted: 23 December 2021 
path, and speed, as well as educational and technology assets to facilitate online engagement (Saboowala \& Manghirmalani Mishra, 2021). According to research, blended learning enables students to study more flexibly and freely, without being constrained by geography or time constraints (Verawardina et al., 2020). Due to the reduced amount of class meetings, the blended learning paradigm increases student performance and results in more effective learning. Additionally, this strategy allows teachers to devote more time to learning activities that engage students in developing their talents (Graham et al., 2013).

Using meta-analysis techniques, this paper evaluates and explains the implementation of blended learning models in pandemic situations. The purpose of this study is to determine the effect of blended learning on learning outcomes. This research is confined to the year 2021 in Indonesia's pandemic period, based on studies from various levels of schooling. Several prior research using the same technique concluded that blended learning results in flexible learning incorporating various facilities and engagement activities. However, in its implementation, a distinct balance of offline and online learning must be maintained (Verawardina et al., 2020). While in research (Balakrishnan et al., 2021) indicates that blended learning improves performance and academic achievement in pharmaceutical education, conventional instruction does not. The COVID-19 epidemic fundamentally altered the educational landscape, changing it from traditional classroom instruction to online learning.

Additionally, blended learning is thought to be capable of improving learning outcomes at all levels of school. Its application to primary school pupils is mainly concerned with exploration to build knowledge and engage with contextual learning environments. At the same time, implementation at the junior high school level focuses more on collaboration for the advancement and application of science. At the senior level, high school and college place a greater emphasis on freedom and collaboration when developing ideas or concepts. However, blended learning has a moderate effect on motivation and self-regulated learning (Lusa et al., 2021).

\section{- METHOD}

The meta-analysis method was utilized in this study, a quantitative statistic used to aggregate the results of prior research to get a definitive conclusion. Meta-analysis is the statistical examination of a collection of research-based individual analyses in order to combine the findings (Santos \& Prudente, 2021). Meta-analysis is a type of survey that makes use of secondary data. The secondary data for this study comes from the post-test scores for experimental and control courses in an article on blended learning application research (Mubai et al., 2021).

Meta-analysis was performed in this study to assess various degrees of comprehension of a publication. Meta-analysis is also defined as the process of categorizing a subject, theme, or field of research according to specific criteria and evaluating the results quantitatively. Meta-analysis is a statistical technique that allows for the generalization of data from several studies (Öztop \& Nayci, 2021).

\section{Identification and Data Collection}

This step is used to identify and gather data for the studies included in the metaanalysis. Primary indexing services such as Google Scholar and Scopus are utilized by databases via publish and perish software. The investigation was conducted in 2021, presuming that a pandemic had already begun that year. 
Specific criteria must be completed (Yakar, 2021) (Öztop \& Nayci, 2021) in order to determine which studies should be included in this meta-analysis:

- Studies in the form of articles published in national or international reference journals or published in Indonesian or English published in 2021.

- Each research must conduct a comparison of the experimental and control groups. Each group's pre-and post-test values must be determined and the statistical data necessary for computing the effect size.

- Studies should have the statistical information necessary for meta-analysis such as sample size, average, standard deviation, etc.

Figure 1 demonstrates and highlights the complete process of identifying and selecting studies for this study.

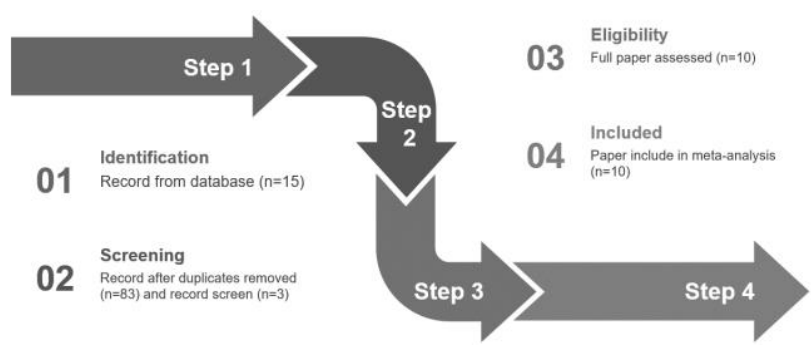

Figure 1. Flow diagram of article selection proses

\section{Effect Size and Data Analysis}

Meta-analysis necessitates the representation of scientific investigations in terms of the magnitude of the effect. The frequency of phenomena in a population or the standard value for different scaling instruments in each research can be used to quantify an impact. Applying various impact size indices is critical for getting traditional values and presenting accurate study findings or interpretations (Yilmaz \& Batdi, 2021). The primary effect size was calculated using a standard average difference, an estimate of weight between the experimental and control groups in the study. This study demonstrates the size of the favorable effect. The post-test is employed to compute effect size to adjust for variations in settings such as prior trials (Robat et al., 2021). Effect size formula as follows:

$$
E S=\left(M_{e}-M_{c}\right) / S D
$$

Where ES represents the effect size, $M_{e}$ is the mean of the experimental class, $M_{c}$ represents the mean of the control class, and SD denotes the combined expected value. This calculating method generates results that are then interpreted in terms of the impact size classification table (Cohen et al., 2002). The effect size criteria are calculated on a four-point scale: extremely low (0.00 - 0.20), low (0.21-0.50), medium (0.51-1.00), and high (more than 1.00).

\section{- RESULT AND DISCUSSION}

Post-test data were collected following a study of ten research publications on blended learning post-pandemic in Indonesia, based on learning outcomes from control and experimental classrooms across many disciplines. Table 2 summarizes the data gathered: 
Table 2. Meta-analysis data of articles related to blended learning in 2021

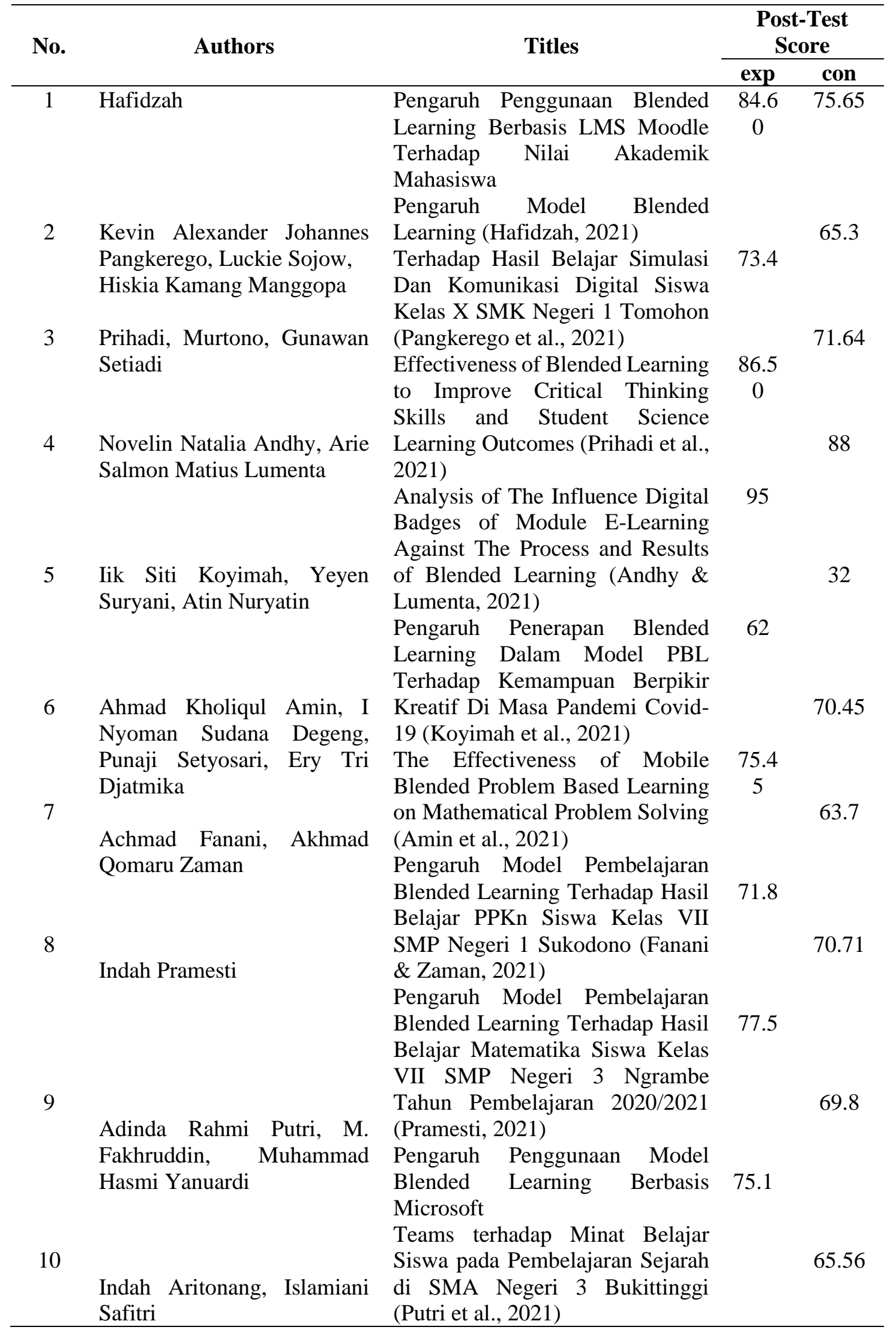




\begin{tabular}{llrc}
\hline Pengaruh & Blended & Learning & 90.4 \\
Terhadap Peningkatan Literasi & 1 \\
Matematika Siswa (Aritonang \& & \\
Safitri, 2021) & \\
\hline
\end{tabular}

Table 1 summarizes peer-reviewed studies and post-test data from experimental and control classes regarding the effect of several disciplines on blended learning. The findings of this table are depicted in figure 2 below as a graph. The analysis of the effect of digital badges on Moodle e-learning using experimental research methodologies obtained the highest scores in both the experimental and control classes. The results indicated that the learning model utilizing badges in Programming I had a more significant impact on student learning outcomes than traditional learning models / no use of badges.

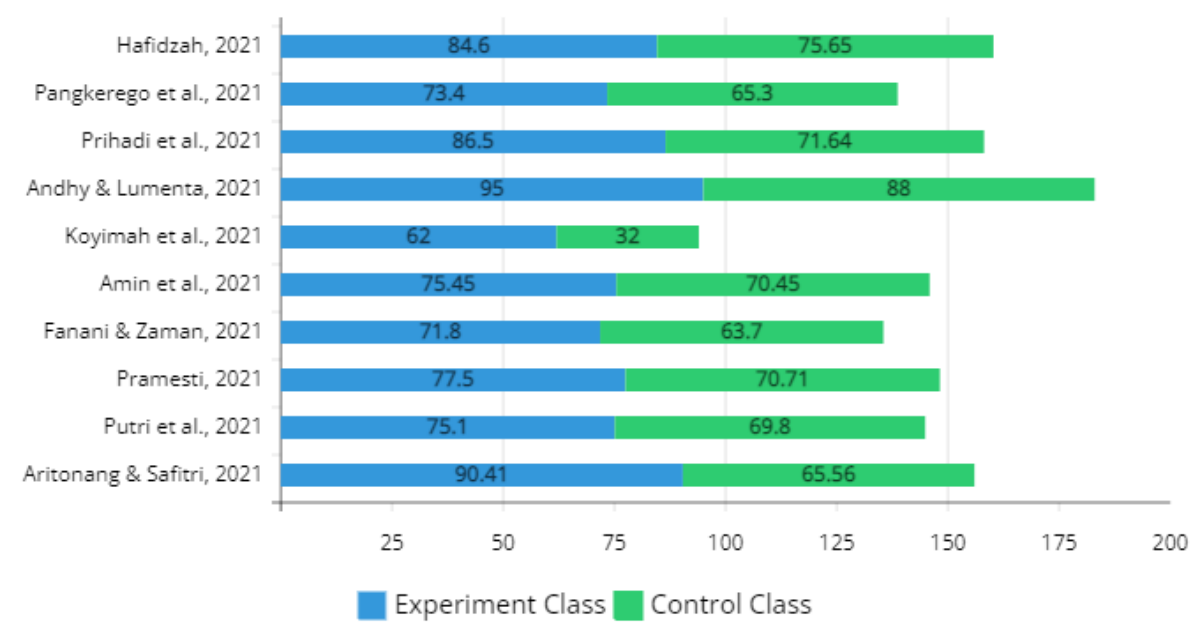

Figure 2. Data tabulation

The results indicated that out of 10 articles examined, the average gain in the experimental class was 79.18, and in the control class was 67.29. As a result, the standard deviation for these two classes is combined with being 9.86. Table 2 summarizes the statistical analysis's findings based on each article's post-test score.

Table 3. Statistical results

\begin{tabular}{rrrl}
\hline \multicolumn{1}{c}{ Class } & Mean & n & \multicolumn{1}{c}{ SD } \\
\hline Experiment Class & 79.18 & 10 & 9.10 \\
Control Class & 67.29 & 10 & 10.57 \\
pooled standard deviation & 9.86 \\
p-value for difference in SDs & 0.33 \\
& Mean Difference & 11.89 \\
Effect Size & 1.21 \\
\hline
\end{tabular}

The data in Table 3 represent the results of testing two classes. Along with the standard pooling value, a p-value of 0.33 was obtained for the difference in SDs. While the average difference is 11.89 , the effect size is 1.21 . According to the interpretation in Table 1, blended learning methods significantly influence learning outcomes during pandemics. According to the paper, blended learning increases learners' enthusiasm to 
learn and improves learning outcomes, as indicated by the highest post-test scores in experimental and control classrooms (Abroto et al., 2021). While another study indicates (Rahayu \& Iswari, 2021) that students who use blended learning approaches Achieve Minimum Completion (KKM) with enhanced cognitive learning results in the moderate category. Additionally, blended learning can help students enhance their critical thinking abilities and academic achievements in science subject (Prihadi et al., 2021). While blended learning, as implemented through Moodle as a Learning Management System (LMS), affects cognitive learning outcomes and student freedom (Sari \& Amalia, 2021).

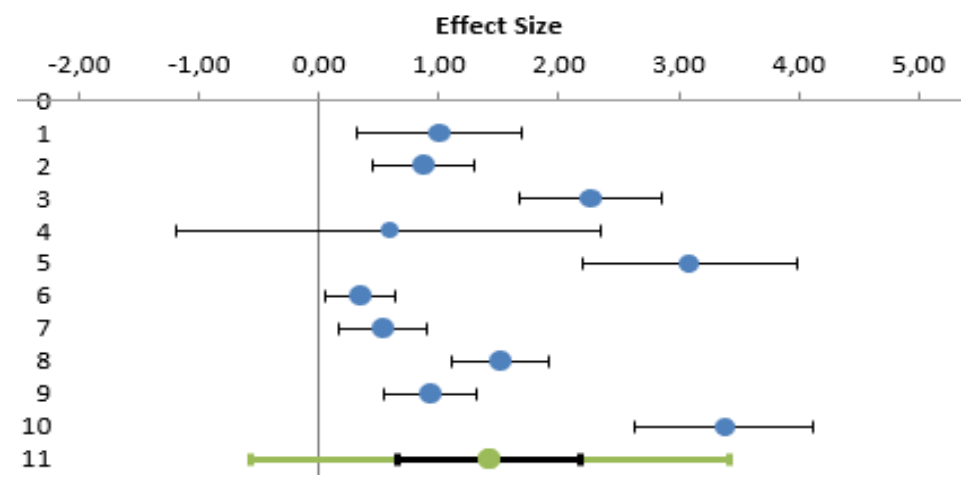

Figure 3. Forest plot of effect size

Figure 3 illustrates a graphic forest plot for each size effect identified in each research. Only one research found a negative effect size ranging from -0.74 to 1.78 (Andhy \& Lumenta, 2021), whereas the other studies found a positive effect size. Because the aggregate size effect value is significant, blended learning approaches used during the pandemic in 2021 will significantly impact learning outcomes.

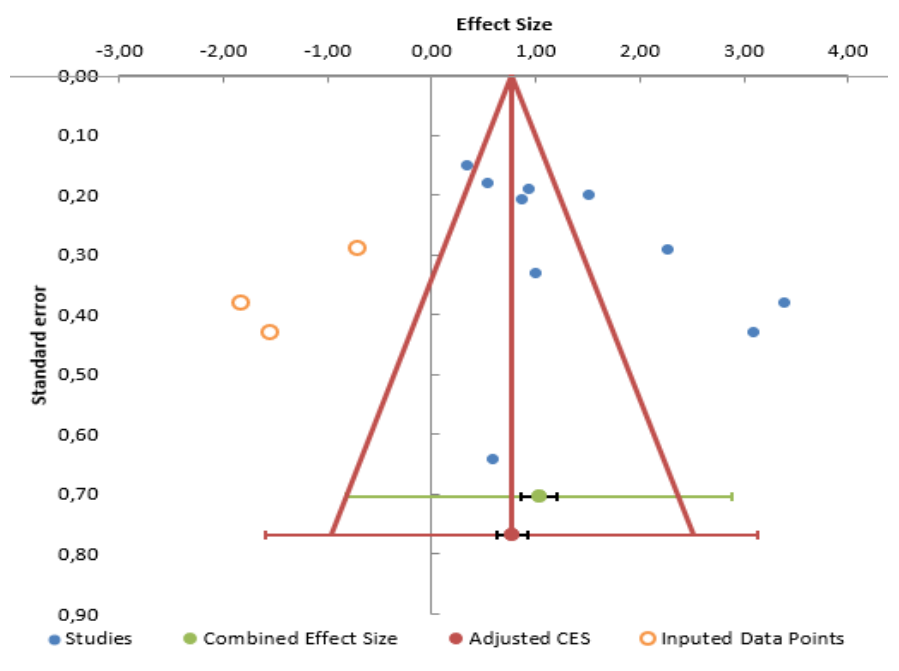

Figure 4. Funnel chart

However, in Figure 4 Funnel Chart, there are indicators of publication bias due to the asymmetry of the effects size research. Egger tests in Table 4 confirm this, with pvalue of 0.038 higher than the significance level of 0.05 . 
Table 4. Egger regression

\begin{tabular}{lllll}
\hline & Estimate & SE & CI LL & CI UL \\
\hline Intercept & 6.17 & 2.48 & 0.55 & 11.79 \\
Slope & -0.30 & 0.57 & -1.60 & 1.00 \\
& \multicolumn{3}{c}{ t-test } & 2.48 \\
& \multicolumn{3}{c}{ p-value } & 0.038 \\
\hline
\end{tabular}

\section{- CONCLUSION}

The use of blended learning models during pandemic periods significantly impacts learning outcomes, as indicated by a size effect value of 1.21 based on ten publications evaluated. Only one research showed a negative effect size between -0.74 and 1.78 , while another produced a positive effect size between -0.74 and 1.78 . This elevated level of impact results in an increase in the desire for learning outcomes. Additionally, blended learning has been shown to boost learners' critical thinking abilities. However, the findings of this study indicate that publication bias exists as a result of the distribution of asymmetrical size effects on the Funnel Chart.

\section{- REFERENCES}

Abroto, A., Maemonah, M., \& Ayu, N. P. (2021). Pengaruh Metode Blended Learning Dalam Meningkatkan Motivasi dan Hasil Belajar Siswa Sekolah Dasar [The Effect of Blended Learning Method in Improving Motivation and Learning Outcomes of Elementary School Students]. EDUKATIF : JURNAL ILMU PENDIDIKAN, 3(5), 1993-2000. https://doi.org/10.31004/edukatif.v3i5.703

Amin, A. K., Sudana, I. N. D., Setyosari, P., \& Djatmika, E. T. (2021). The Effectiveness of Mobile Blended Problem Based Learning on Mathematical Problem Solving. International Journal of Interactive Mobile Technologies (IJIM), 15(01), 119. https://doi.org/10.3991/ijim.v15i01.17437

Andhy, N. N., \& Lumenta, A. S. M. (2021). Analysis Of The Influence Digital Badges Of Module E-Learning Against The Process And Results Of Blended Learning. Jurnal Teknik Elektro Dan Komputer, 10(2).

Aritonang, I., \& Safitri, I. (2021). Pengaruh Blended Learning Terhadap Peningkatan Literasi Matematika Siswa [The Effect of Blended Learning on the Improvement of Students' Mathematical Literacy]. Jurnal Cendekia: Jurnal Pendidikan Matematika, $5(1)$.

Balakrishnan, A., Puthean, S., Satheesh, G., M. K., U., Rashid, M., Nair, S., \& Thunga, G. (2021). Effectiveness of blended learning in pharmacy education: A systematic review and meta-analysis. PLOS ONE, 16(6), e0252461. https://doi.org/10.1371/journal.pone.0252461

Cohen, L., Manion, L., \& Morrison, K. (2002). Research Methods in Education (5th Editio). Routledge. https://doi.org/10.4324/9780203224342

Fanani, A., \& Zaman, A. Q. (2021). Pengaruh Model Pembelajaran Blended Learning Terhadap Hasil Belajar PPKn Siswa Kelas VII SMP Negeri 1 Sukodono [The Effect of Blended Learning Learning Model on Civics Learning Outcomes for Class VII Students of SMP Negeri 1 Sukodono]. PACIVIC (Jurnal Pendidikan Pancasila Dan Kewarganegaraan), 1(1).

Firman Edi, Ambiyar, A., Verawardina, U., Samsir, S., \& Watrianthos, R. (2021). Improving Lesson Plan Models Using Online-Based in the New Normal Era. EDUTEC: Journal of Education And Technology, 4(3), 527-535. 
https://doi.org/10.29062/edu.v4i3.109

Graham, C. R., Woodfield, W., \& Harrison, J. B. (2013). A framework for institutional adoption and implementation of blended learning in higher education. The Internet and Higher Education, 18, 4-14. https://doi.org/10.1016/j.iheduc.2012.09.003

Hafidzah. (2021). Pengaruh Penggunaan Blended Learning Berbasis LMS Moodle Terhadap Nilai Akademik Mahasiswa Pengaruh Model Blended Learning [The Effect of Using Moodle LMS-Based Blended Learning on Students' Academic Values The Effect of Blended Learning Model]. Jurnal Ilmiah Teknologi Dan Rekayasa, 25(3).

Koyimah, I. S., Suryani, Y., \& Nuryatin, A. (2021). Pengaruh Penerapan Blended Learning Dalam Model PBL Terhadap Kemampuan Berpikir Kreatif Di Masa Pandemi Covid-19 [The Influence of the Application of Blended Learning in the PBL Model on the Ability to Think Creatively During the Covid-19 Pandemic]. Equilibrium: Jurnal Penelitian Pendidikan Dan Ekonomi, 18(2).

Lusa, H., Adnan, A., \& Yurniwati, Y. (2021). Effect of Blended Learning on Students' Learning Outcomes: A Meta-Analysis. Jurnal Pendidikan Progresif, 11(2), 309325. https://doi.org/10.23960/jpp.v11.i2.202113

Mubai, A., Giatman, Jalinus, N., Syahril, \& Abdullah, R. (2021). The Effectiveness of Learning Media Based on Augmented Reality in Vocational Education: A Meta Analysis. Annals of Romanian Society for Cell Biology, 25(4).

Öztop, F., \& Nayci, Ö. (2021). Does the digital generation comprehend better from the screen or from the paper?: a meta-analysis. International Online Journal of Education and Teaching, 8(2), 1206-1224.

Pangkerego, K. A. J., Sojow, L., \& Kamang, M. H. (2021). Pengaruh Model Blended Learning Terhadap Hasil Belajar Simulasi Dan Komunikasi Digital Siswa Kelas X SMK Negeri 1 Tomohon [The Effect of Blended Learning Model on Simulation Learning Outcomes and Digital Communication of Class X Students of SMK Negeri 1 Tomohon]. EduTIK: Jurnal Pendidikan Teknologi Informasi Dan Komunikasi, 1(1).

Pramesti, I. (2021). Pengaruh Model Pembelajaran Blended Learning Terhadap Hasil Belajar Matematika Siswa Kelas VII SMP Negeri 3 Ngrambe Tahun Pembelajaran 2020/2021 [The Effect of Blended Learning Model on Mathematics Learning Outcomes of Class VII Students of SMP Negeri 3 Ngrambe for the 2020/2021 Academic Year]. Indah Pramesti: Pengaruh Model Pembelajaran Blended Learning, 1(2).

Prihadi, Murtono, \& Setiadi, G. (2021). Effectiveness of Blended Learning to Improve Critical Thinking Skills and Student Science Learning Outcomes. Journal of Physics: Conference Series, 1823(1), 012095. https://doi.org/10.1088/17426596/1823/1/012095

Putri, A. R., Fakhruddin, M., \& Yanuardi, M. H. (2021). Pengaruh Penggunaan Model Blended Learning Berbasis Microsoft Teams terhadap Minat Belajar Siswa pada Pembelajaran Sejarah di SMA Negeri 3 Bukittinggi [The Effect of Using Microsoft Teams-Based Blended Learning Model on Students' Interest in Learning History at SMA Negeri 3 Bukittinggi]. Jurnal Pendidikan Tambusai, 5(2).

Rahayu, P., \& Iswari, R. S. (2021). The Effectiveness of Blended Learning Models toward The Motivation and Learning Outcomes of High School Students in Ecological Materials. Journal of Biology Education, 10(2).

Robat, E. S., Khodabakhshzadeh, H., \& Ashraf, H. (2021). The Effectiveness of English 
Language Teaching Methods: A Meta-Analysis in Pursuit for "the Best Method." Journal of Teaching Language Skills, 40(1). https://doi.org/10.22099/jtls.2021.39199.2920

Saboowala, R., \& Manghirmalani Mishra, P. (2021). Readiness of In-service Teachers Toward a Blended Learning Approach as a Learning Pedagogy in the Post-COVID19 Era. Journal of Educational Technology Systems, 50(1), 9-23. https://doi.org/10.1177/00472395211015232

Samsir, Ambiyar, Verawardina, U., Edi, F., \& Watrianthos, R. (2021). Analisis Sentimen Pembelajaran Daring Pada Twitter di Masa Pandemi COVID-19 Menggunakan Metode Naïve Bayes [Sentiment Analysis of Online Learning on Twitter during the COVID-19 Pandemic Using the Nave Bayes Method]. Jurnal Media Informatika Budidarma, 5(1), 157-163. https://doi.org/10.30865/mib.v5i1.2604

Santos, M. L., \& Prudente, M. (2021). Effectiveness of Virtual Laboratories in Science Education: A Meta-Analysis. International Journal of Information and Education Technology, 11(12).

Sari, R. N., \& Amalia, A. V. (2021). The Effectiveness of Blended Learning Using Moodle on Student Independence and Learning Outcomes. Journal of Environmental and Science Education, 1(1).

Verawardina, U., Jalinus, N., \& Krismadinata. (2020). Needs Assessment of E-Learning Vocational Education. Journal of Innovation, Creativity and Change, 11(4).

Yakar, Z. Y. (2021). The Effect of Flipped Learning Model on Primary and Secondary School Students' Mathematics Achievement: A Meta-Analysis Study. Çukurova Üniversitesi Ĕ̈itim Fakültesi Dergisi, 50(2), 1329-1366. https://doi.org/10.14812/cufej.865337

Yilmaz, Z. A., \& Batdi, V. (2021). Meta-Analysis of the Use of Augmented Reality Applications in Science Teaching. Journal of Science Learning, 4(3). 